\title{
Hidden treasures: The Jagiellonian Museum, Kraków
}

\author{
Poland's oldest university museum celebrates the Sun-centred ideas of Copernicus and the history of the \\ nation itself, explains Alison Abbott.
}

Nicolaus Copernicus was, they say in Kraków, one of the city's first tourists. He 'almost certainly' visited its famous salt mines, they insist. And indeed, some 150 metres underground, among the statues of saints and heroes in the labyrinth of chapels and chambers carved out of the salt rock by miners over the centuries, stands an imposing likeness of Poland's most famous scientist - the man who worked out that Earth orbits the Sun.

Copernicus was a student in Kraków from 1491 until 1495, during one of Poland's intermittent spells of greatness in between the long periods of oppression by its neighbours Russia, Prussia, Sweden and Austria. More than a century earlier, Wladyslaw I the Elbow-high, a fine warrior who was crowned king in 1320, brought the necessary order, unity and wealth to the fragmented chaos of the Polish territories to give his son and (no doubt taller) successor, Casimir III the Great, the ability to create institutions worthy of an aspiring European power. The Kraków Academy was founded by papal decree in 1364, making it one of the oldest seats of learning in Europe.

But the academy - now known as the Jagiellonian University - only really took off in 1400, thanks to the vision of Queen Jadwiga, one of the first regents to be democratically elected from among the increasingly powerful Polish nobility. She bequeathed her wealth to the university, leaving her illiterate widowed husband to realize her plans. Uniquely for its time, its professors did not have to depend on student fees for their income. Instead, they were paid from the proceeds of the salt mines, which stopped full operation only in 1996.

Throughout the fifteenth century, the university's reputation soared. It attracted students from all over Europe, thanks in no small part to its strength in mathematics and astronomy. Copernicus must have benefited from its special intellectual atmosphere, even though a fire swept through the campus the year after he arrived, razing it to the ground. The lovely Collegium Maius - then, as now, the main seat of the university - was built on the ashes, a beautiful square of gothic buildings around a courtyard that was given a neo-Baroque makeover in the mid-nineteenth century. The college attracts as many tourists today as the popular salt mines. It also houses the Jagiellonian Museum, which brings together scientific instruments from the university's glory days, collections put together by professors over the centuries and bequests from grateful students that continue today.

But by the mid-sixteenth century, the university's glory was waning. Polish nobles lost their noble vision
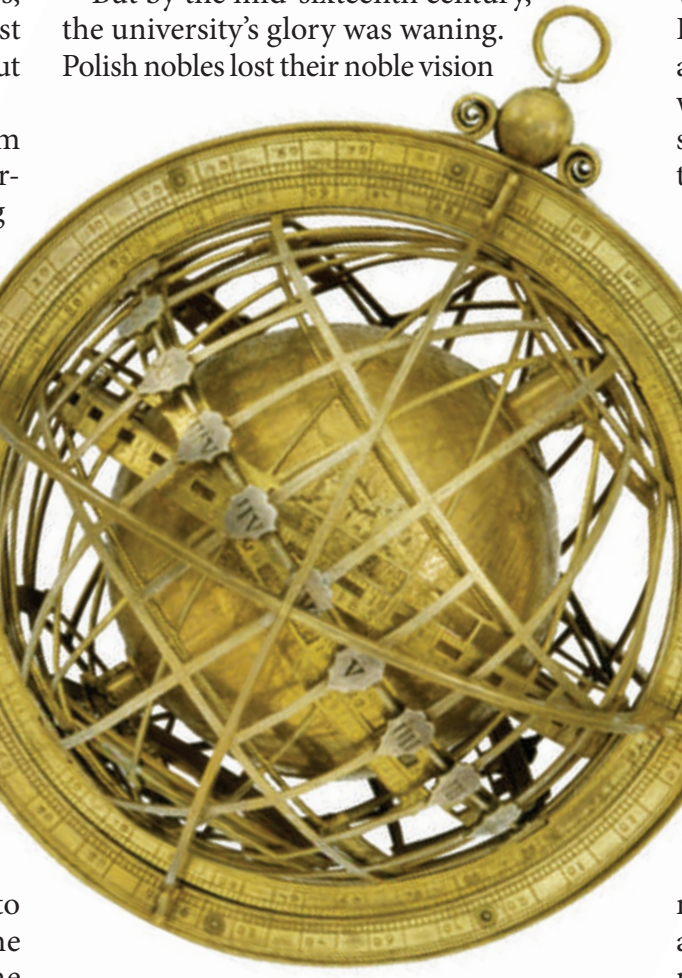

The gilded Jagiellonian Globe within its armillary sphere is the first to show the Americas.

and began to use their power to promote their own self-interests. They decided that offices of the state and church should be allocated exclusively from among their number, making higher education less valuable. The university faculties became embroiled in a decades-long struggle with the Jesuits, who wanted to establish a rival academy. And at the same time, wars, epidemics and other disasters were taking their toll on the weakening Polish state. The university stagnated, although the renowned astronomer and mathematician Jan Brożek (1585-1652), worked there during this time. A committed propagator of the Copernican heliocentric theory, Brożek also collected many of the important astronomi$\mathrm{cal}$ artefacts now on view in the museum.

The Enlightenment arrived late in Poland, reaching its peak in the 1770 s, and was brief. Students were sent abroad to observe research and bring that scientific culture back to their alma mater. But many never had a chance to return. By 1795, a series of three partitions Russia annexing from the east, Prussia from the west and Austria from the south — had wiped Poland from the map. The country did not exist again until after the First World War. Kraków was swallowed up by Austria, and returning scholars found themselves ineligible to work at the exclusively German-speaking university.

Eighty years passed and the university began to flourish once more, at least until the First

World War. One of its triumphs during that time was the first liquefaction of the components of air in a stable form, by chemist and instrument-maker Karol Olszewski and his colleague Zygmunt Wróblewski.

The disaster that was wrought by the two twentieth-century world wars is well known. But the university never closed down, and the Collegium Maius has been spruced up since the fall of the Iron Curtain. Its extensive museum includes among its countless treasures the famous Jagiellonian Globe, which shows the American continents for the first time. Made around 1515 and acquired by Brożek, the 7-centimetre-diameter globe is surrounded by an armillary sphere and includes a clock mechanism. The museum also houses a vast, valuable collection of optical instruments, including many telescopes, and Olszewski's beautifully crafted cryogenic equipment.

Copernicus never returned to Kraków after his student days. But in the 1950s, the museum commissioned the construction of three massive timber instruments of the type that Copernicus probably used - a quadrant, a triquetrum and a skeletal armillary sphere, all of which measured the position of celestial objects in the pre-telescope era. The majestic trio, which stand between 1.5 and 2.5 metres high, are as much a homage to science as the Copernicus salt statue deep inside the Earth. Alison Abbott is Nature's senior European correspondent.

See http://tinyurl.com/5ash6p. For more Hidden treasures, see www.nature.com/nature/focus/ hiddentreasures. 